\title{
Theoretical and Empirical Background for a Higher Education Model of Active Community Learning
}

\author{
Gabriella Pusztai ${ }^{1}$, Zsuzsanna Demeter-Karászi ${ }^{2}$, Tímea Szücs ${ }^{3}$ \\ ${ }^{1}$ Institute of Educational and Cultural Management, University of Debrecen, Hungary, \\ ${ }^{2}$ Institute of Educational and Cultural Management, University of Debrecen, Hungary, \\ ${ }^{3}$ Institute of Educational and Cultural Management, University of Debrecen, Hungary.
}

\begin{abstract}
The intertwining of research and education at CHERD Higher Education Research and Development Center (CHERD) at the University of Debrecen performed several basic and applied research on Higher Education. Debrecen is a typical regional HE institution with international attraction in the peripheral area of EU. We performed a series of student surveys during the last decade, and we had the opportunity to reveal the process of gaining ground of non-traditional students in HE. Our center provides an inspiring context for researchers, where they have opportunity to discuss their formulating new research directions and to interpretat data and research results together. The Center supports talent esplorations and-development. Both MA/PhD students and researchers with great experience work together as a learning community. Thus, the mutual transfer and exchange of experience makes possible a continuous teachinglearning process during the research. Further more the concentration of professional development increases a special form of social capital.
\end{abstract}

Keywords: research and education; higher education research; talent management; reform process. 


\section{Introduction}

The Centre for Higher Education Research and Development (CHERD) at the University of Debrecen plays an essential role in the educational and talent development activity of the institution. One of the most important aspects of the multidimensional relationship is to involve students in the activity of the research centre, thus creating an opportunity for them to learn how to interpret scientific literature, to formulate questions and hypothesis, to carry out research tasks, and last but not least, to write articles and conference presentations. We offer training for students who wish to continue their studies at a higher level and for those who wish to take part in competitions. In order to achieve our goals, students need to work on real projects, not fictitious ones, and learn how to work in a team in which each member's idea is equally important and they all equally contribute to the end result. This in practice is the active learning pedagogical model in higher education. During the active learning students participate in planning, they gets the opportunity to analyze, to synthesis and also to evaluate (Bonwell\&Eison, 1991). The criterion of the active learning is that the students have to carry out a responsible task (Bolden et al., 2017). The present research is an overview of the theoretical and empirical results underlying this higher education teaching method ${ }^{1}$.

\section{The transformation of faculty roles}

According to European university traditions the teacher-student relationship is basically confined to scientific communication by means of which teachers publicly express their scientific views, while students engaged in their studies, formulate questions, or sometimes debate (Szczepanski, 1969). The differentiation of the roles of higher education (Castro\&Levy, 2001), as well as the rising numbers of students has led to the separation of the functions of teacher and researcher, and has given rise to role conflicts in higher education $^{2}$ (Szczepanski, 1969; Clark, 1987; Kozma, 2004). Teachers and students were distanced not only by the difference in age but also by the pressure of symbolic power asymmetry, which further deepened the generation gap. Bourdieu found that pedagogical relation is not merely a matter of communication and that there is a strong correlation between linguistic capital and the selection taking place during the first academic years. Students' understanding and language use serve as a basis for teachers' evaluation. Language is not merely a means of communication but rather a system of categories hereditary transmitted, characterized by logical and aesthetic features which constitute a long lasting characteristic of students (Bourdieu, 1988).

According to Bourdieu teachers possess inherited (place of living, parents, status, denomination) and acquired (career, titles, awards) capital. The academic community, which Bourdieu considers a conservative community protecting its position, is led by

\footnotetext{
${ }^{1}$ An earlier version of the study was published in Hungarian in one of the chapters of Pusztai (2011).

2 Further research could be carried out on the effects of career opportunities and the social position of this occupational group on teachers' behaviour pattern. The present study does not address this issue.
} 
people in administrative positions. They enjoy the capital of academic authority, which in principle does not depend on scientific excellence. It takes a large amount of time to accumulate it, however it ensures power over the internal network of the institution. The group is characterized by a traditional spirit, newcomers are carefully selected, rigorously targeted, and melted in, i.e. co-opted. They can join the privileged circle of faculty after long waits for inheriting certain positions, in order to climb the rungs of the ladder. In the American literature of the field a contrast is drawn between teacher and researcher, i.e. higher education staff either dedicated to teaching or doing scientific research. Bourdieu, on the other hand, makes a distinction between an administrative or an academic career.

He draws attention to the fact that the crisis in higher education caused changes not only in the student community but also in teacher dispositions. A number of professors, invoking the preservation of elite education, insist on competitions and "numerous clausus" for both student and teacher advancement (Bourdieu, 1988). The security of the career path of those who wish to maintain the rules for academic advancement has deteriorated. A part of the emerging faculty has chosen the rapid return on knowledge capital (money, public honour) avoiding the time- and energy- consuming promotion rites, and departing from academic conventions, which were characterized by patience and performance-based eligibility. Nonetheless, in this model, neither the traditional nor the changed roles of teachers facilitate students' successful career (Pusztai, 2011).

\section{Lonely students in crowd}

Besides changed teacher roles, the relationship in question is also influenced by the fact that higher education has shifted toward an economic subsystem. Profit maximization has become one of the fundamental values of academics, or in some cases it has even replaced these values and has led to increasing alienation and anomie among students. Some claim that alienation can be associated with the lessening of requirements and the time nedded for study (Bryson\&Hand, 2007); others blame it on the decline in career opportunities during and after study (Bourdieu, 1988; Bargel et al., 2009).

A number of researchers claim that higher education institutions are breeding ground for student loneliness, and personal relationships are the only counterbalance for the feeling of impersonality within the institution (Pusztai, 2011). Alienation is one of the major components of student isolation. Students feel that they are not treated as individuals; at best they are treated as clients. The focus is only on their performance, absences over a prolonged period are not noticed, and they are never approached by anyone. According to German researchers one third - two fifths of students are affected by these phenomena (Bargel et al., 2008). Research results show that teachers' unapproachability and the high rate of students lacking contact varies among institutions and academic discipline ${ }^{3}$.

\footnotetext{
${ }^{3}$ At universities half as many are experiencing relationships as at colleges. More than one third of the students of humanities and natural sciences maintain some kind of contact with their teachers, while in the case of students of law and economic sciences this ratio is only one sixth (Bargel et al. 2008).
} 
Nonetheless, there is little information on how students of different social backgrounds are affected by this ${ }^{4}$.

A number of specialized institutional services have emerged within higher education institutions trying to tackle this problem (Harper\&Quaye, 2009). However with lowerstatus students this solution is not always viable. They profit less from the help of specialist; they rather turn to their teachers because they are deterred by the client approach of these targeted institutional units (Thomas\&Jones, 2007; Greenbank\&Hepworth, 2008). The great hope, the internet, has somewhat improved the rate of those experiencing relationship, however it has very slightly reduced students' perception on and their dissatisfaction with isolation (Bargel et al., 2008).

\section{The importance of student-faculty relations}

"Being taken into account", the perception of genuine concern has a particularly important impact in the world of education (Pusztai, 2008). It is not new, that social competences are usually the most important expectations student have from their teachers. These are what serve as a basis for an ideal picture of a friendly, understanding, helpful and likable teacher (Szczepanski, 1969). In the process of verifying Coleman's asymmetric effect thesis we pointed out that lower-status students place more value on teachers' attention (Pusztai, 2009a). Research on efficient learning also points out that the positive role of a teacher takes effect if the dimensions of interpersonal relationship encompass all aspects of students' personality (being treated as a person, being greeted, getting feedback, and being complimented) (Gaskó\&Kálmán, 2014; Márkus\&Engler, 2019).

As regards behaviour patterns related to the educational role in each institution, or rather within a faculty, a special consensus takes shape. This is perceived by newer generation of student as natural environment. Consequently, students lacking any point of reference can hardly reflect on this issue, except students who come from other institutions. Even though these local behaviour standards are difficult to measure, their contribution to the student environment is a key building block of student's commitment, since their role fulfilment is heavily dependent on those who play a complementary role (Szczepanski, 1969).

Studies on how teachers perceive their own role show a significant uncertainty in this area. Contrasting students' and teachers' conceptions, it is unequivocal that while students find it useful and important to have a relationship based on trust and informal communication with their teachers, the latter give voice to their disappointment with students and consider that it is in the student' s own interest and responsibility to be committed (Bryson\&Hand, 2007). Another approach considers that a student- teacher relationship based on personal contact can pose an ethical risk, given the dangers of the duality of official and personal relationships, and cases of abuse of allowances and trust (Blevins-Knabe, 2006; Klatt, 2006). Behind this lies the conviction that treating students as clients poses fewer risks.

Student-teacher interactions had a decisive role in the early models of student integration. Even the earliest findings attested to the fact that any type of formal or informal

\footnotetext{
${ }^{4}$ Ez a kutatás az oktató-hallgató kapcsolat mutatóiként a következőket alkalmazta: fogadóórai találkozás, informális tanácsadás, bevezető, orientáló foglalkozás és vizsgaelökészítés (Bargel et al., 2008).
} 
relationship with the teacher has a positive effect on students' achievement, commitment and satisfaction (Gaff\&Gaff, 1981; Milem\&Berger, 1997). This is often stated in the literature, however the majority of researchers only mention the significant correlation between the variables but they very rarely undertake the investigation of the operational mechanisms or a theoretical interpretation of the phenomenon. It is also very uncommon for researchers to qualify the nature of student-teacher communication.

From students' point of view teachers can exert the most influence through an intellectually stimulating relationship. Shaping teachers' and students' knowledge through disputes is one of the most outstanding and lasting specialties of higher education. The lack of relationship can also be interpreted as the manifestation of an intellectual incompetence for debates or discussions, which according to all paradigms leads to resource deficit. The mere presence and availability of teachers already has a positive effect since it creates an impression of reliability, which indicates the "strength of social capital" in a relationship (Coleman, 1988). According to Bryk and Schneider increasing trust in role partners in educational institutions contributes to improved educational outcomes (Bryk\&Schneider, 2002; Pusztai, 2009). In order to achieve this, collaborators have to be assured that taking their interests into account is mutually important and that work is carried out in an honest and competent manner. Thus, student-teacher interactions also show students how committed the institution is to them.

There is a further aspect which confirms that trust in teachers goes beyond its primary significance. Departing from Simmel's theory of general trust and accepting that interpersonal trust is the basis for generalized trust, it follows that trust in teachers could advance trust in higher education. According to Lin (2005) there is no knowledge of how this generalized trust develops. We are also investigating the source of general trust which could arise from the number of trustworthy people in one's own personal network, or perhaps from the number of peers who also trust teachers (Pusztai, 2014).

In the interaction model the role of student-teacher communication is to create an opportunity for social comparison. Students can measure up their dispositions to the values and norms of the representatives of the academic environment, and they can receive information on the congruency of their own values and norms. The more contacts, the higher the level of conformity and congruency. Frequent contacts can also have anchoring results, i.e., they can correct the consequences of students drifting between identity- and value orientation (Berger\&Milem, 2000). The simplified view on teachers presented in these models does not take into account the fact that similarly to students' culture teachers' culture has become pluralized giving rise to different institutional manifestations of confrontations yielding very different results.

Following to the logic of Coleman's social capital theory, the active presence of the teacher contributes to the cohesion of the institutional social network also in other ways. Encouraging performance through control is only one of the numerous effects it can have. In this respect the student integration theory again shows similarity to Coleman's social capital conception, which also claims that, the more frequent and versatile communication is, the higher the chances for academic success. Nonetheless, the social capital educational theory explains this with the mutual exchange of norms and control promoting the achievement of a greater level of performance. Thus, this theory raises not only the 
question of connectivity but also the question of the embeddedness into the system of norms (Pusztai, 2015).

According to the social capital theory, apart from the frequency, it depends on the quality and versatility of communication whether resulting benefits will have an effect on students' career, especially in the case of low-status, non-traditional students (Jaeger\&Eagan, 2009). Teachers' conduct is part of the institutional conduct and it can contain many features related to the unequal treatment of low-status students as identified by Bourdieu. Lower expectancy as compared to middle-class students, as well as traditional educational features favouring higher-status students: the language of education, assumed knowledge, as well as favouring style as opposed to content (Thomas, 2002). Relating to teachers in the classroom has its own rite, usually characterized by passivity and distance keeping on the students' part. Despite the transformation of higher education, the type and choreography of classes have barely changed. For a long time, the breakthrough in the modernization of higher education pedagogy was seen exclusively in the use of information and communication technology. Nonetheless, in the international literature there is a growing emphasis on the following topics: rethinking the content of higher education pedagogy, classroom atmosphere, identifying more efficient solutions for the personal advancement of students, students' participation, and investigating active and community learning (Astin, 1987).

More recently, the European literature on higher education pedagogy has been formulating expectations regarding high-school teachers. Among the inclusive higher education behaviour indicators defined on the basis of students' perceptions we find: the constructive management of the academic problems of previously underrepresented groups of students, support offered in shaping and fine-tuning academic aspirations, personal evaluation and interpretation of educational achievements, as well as expressing personal interest (calling students on their names) (Thomas, 2002; Pusztai, 2011).

The changes in the nature of teaching relate to the quality and quantity of communication with students. This has also affected the relationships within the institution and students' contribution to the benefits arising from these (Pusztai, 2011). The cost-effective increase in the teacher-student ratio, the competition against research-related activities, or part-time teachers' multiple identity significantly reduces the time spent teaching. Approaches to occupational status deal with the aspects of working hours and position within the institution. It is true that part-time teachers reduce the costs of the institution, however they are not available to students, they develop less relationships, they require less from students or have lower expectations from them, and they are less often chosen as thesis supervisors (Umbach, 2007; Jaeger\&Eagan, 2009).

Teachers' time management in favour of a certain institution was always considered a source of social capital, which helps not only solve school related problems but also creates solidarity with the tasks of the institution (Bryk et al., 1992). International studies show that part-time teachers in higher education identify less with the culture and special tasks of the institution, moreover they are usually dissatisfied with the work they do (Jaeger\&Eagan, 2009). Studies in our country have not dealt with this issue yet, however we have proposed an alternative hypothesis that part-time teachers can bring new information and opportunities to the institution. This however can offer results only at the highest levels of university education (Pusztai, 2009b). 
One of our previous investigations has focused on the fact that there might be a connection between teachers' availability and efficiency not only on BA and MA level but also on $\mathrm{PhD}$ level (Pusztai, 2009b). Views differ on what kind of social networks would benefit $\mathrm{PhD}$ students in a successful academic career and what types of ties (weak, strong, bridge or connecting) are more influential among them. The extent to which the network of supervisors, tutors, and $\mathrm{PhD}$ students can have an impact also depends on the discipline and the culture of the institution. Studies show that ties extending to supervisors and teachers in the $\mathrm{PhD}$ programme, as well as embedding into the academic network play a significant role not only in completing the dissertation (Lovitts, 2001) but also in conveying values, norms and behaviour patterns. Weak institutional embeddedness of $\mathrm{PhD}$ students can forecasts inefficiency in their $\mathrm{PhD}$ studies (Austin, 2002; Pusztai, 2011). All these emphasise the importance of workshops functioning as real academic communities, as opposed to $\mathrm{PhD}$ programmes involving so called "dead souls", i.e., PhD students working in isolation. While carrying out research investigating $\mathrm{PhD}$ programmes we found among indicators measuring integration not only indicators related to research (research group membership, joint publication, academic or professional association membership) but also such indicators as working in the same office with the teacher, or having common leisure activities, e.g. sports (Lovitts, 2001; Pusztai, 2011).

Our quantitative studies show that formal and informal institutional relationships of integration have the strongest and most stable effect on student efficiency. In order to achieve better than average results, students enrolled in higher education in the region under scrutiny by CHERD need a sufficient quantity and quality of communication with their teachers on various topics. Students need academic, scientific, intellectual and public life discourse on a regular basis and need to reflect on their future plans, personal aptitudes, sometimes even on their academic and personal problems in the light of these (Pusztai, 2011; Pusztai, 2015). Being in agreement with the teachers' worldview is also of crucial importance, especially in the case when it is not the approach advocating high performance that dominates. We have found and presented a number of such cases in the previous chapter. Students can become familiar with the teachers' worldview only through studentteacher interactions and reaching agreement is rather just a possibility in the light of the influence of the interpretive communities which have a different impact (Pusztai, 2011).

\section{References}

Astin, A. W. (1993). What Matters in College: Four Critical Years Revisited. San Francisco, CA: Jossey-Bass.

Austin, A. E. (2002). Preparing the Next Generation of Faculty: Graduate School as Socialization to the Academic Career. The Journal of Higher Education, 73 (1), 94-122. doi: 10.1080/00221546.2002.11777132

Bargel, T., Ramm, M. \& Multrus, F. (2008). Studiensituation und studentische Orientierungen. 10. Studierendensurvey an Universitäten und Fachhochschulen. Bonn, Berlin: Bundesministerium für Bildung und Forschung. 
Bargel, T., Multrus, F., Ramm, M. \& Bargel, H. (2009). BachelorStudierende. Erfahrungen in Studium und Lehre. Bonn-Berlin: Bundesministerium für Bildung und Forschung.

Berger, J. B. \& Milem, J. F. (2000). Orgazinational behavior in Higher Education and Student Outcomes. In Smart, J. C. (Ed.): Higher Education: Handbook of Theory and Research Volume XV (pp. 268-338). Bronx: Agathon Press.

Blevins-Knabe, B. (2006). The ethics of dual relationships in higher education. In Barrow, R. \& Keeney, P. Academic Ethics (pp. 457-473). London: Ashgate.

Bonwell, C. C. \& Eison, J. A. (1991): Active learning: Creating Excitement in the Classroom. ASHE-ERIC Higher Education Reports.

Bourdieu, P. (1988). Homo Academicus. Stanford: Stanford University Press.

Bolden, E.C., Oestreich, T., Kenney, M.J. \& Yuhnke, B.T. (2017). Location, location, location: A comparison of student experience in a lecture hall to a small classroom using similar techniques. Active Learning in Higher Education, 20 (2) 139-152.

Bryk, A. S., Lee, V. E. \& Holland, P. B. (1992). Catholic Schools and the Common Good. Cambridge: Harvard University Press.

Bryk, A. S. \& Schneider, B. (2002). Trust in Schools: a core resource for improvement. New York: Russel Sage Foundation.

Bryson, C. \& Hand, L. (2007). The role of engagement in inspiring teaching and learning. Innovations in Teaching and Education International, 44 (4), 349-362. doi: 10.1080/14703290701602748

Castro, C. de M. \& Levy, D. C. (2001). Four Functions of Higher Education. International Higher Education, 23 (2), 5. doi: 10.6017/ihe.2001.23.6594

Clark, B. R. (1987). The Academic Life: Small Worlds, Different Worlds. Princeton: The Carnegie Foundation for the Advancement of Teaching.

Coleman, J. S. (1988). Social Capital in the Creation of the Human Capital. American Journal of Sociology, 94 (1), 95-120. doi: 10.1086/228943

Gaff, J. G. \& Gaff, S. S. (1981). Student-faculty relationships. In Chickering, A. W. \& Associates (Eds.): The modern American college (pp. 642-656). San Francisco: JosseyBass.

Gaskó, K. \& Kálmán, O. (2014). Learning in Higher Education. In Vámos, Á. \& Lénárd, S. (Eds.): Training programme and organisation in the Bologna process of Hungarian higher education : The BaBe project (pp. 82-98). Budapest: ELTE Eötvös Kiadó. 
Greenbank, P. \& Hepworth, S. (2008). Working Class Students and the Career Decisionmaking Process: a qualitative study. Report for the Higher Education Careers Service Unit (HECSU). Manchester: Edge Hill University.

Harper, S. R. \& Quaye, S. J. (Eds.) (2009). Student Engagement in Higher Education. New York-London: Routledge.

Jaeger, A. J. \& Eagan, M. K. (2009). Unintended consequences: examining the effect of part-time faculty members on associate's degree completion. Community College Review, 36 (3), 167-194. doi: 10.1177/0091552108327070

Klatt, H.-J. (2006). Political correctness as an academic discipline. In Barrow, R. \& Keeney, P. (Eds.): Academic Ethics (pp. 36- 45). London: Ashgate.

Kozma, T. (2004). Kié az egyetem? A felsőoktatás nevelésszociológiája. Budapest: Új Mandátum Könyvkiadó.

Lin, N. (2005). Social Capital. In Beckert, J. \& Zagiroski, M. (Eds.): Encyclopedia of Economic Sociology. (pp. 604-612). London: Routledge.

Lovitts, B. E. (2001). Leaving the Ivory Tower: The Causes and Consequences of Departure From Doctoral Study. Lanham: Rowman and Littlefield.

Márkus, E. \& Engler, Á. (2019). Developing and Methodology of Training Courses for Improving Competence- and Learning Outcomes. In Erdei, G., Juhász, E., Sahin, S. \& Kaan, A. (Eds.): Ways of Promoting Excellence in Higher Education (pp. 107-123). Ankara: Pegem Akademi Yayincilik Egitim Danismanlik Hizmetleri Tic. Ltd.

Milem, J. F. \& Berger, J. B. (1997). A modified model of student persistence: Exploring the relationship between Astin's theory of involvement and Tinto's theory of student departure. Journal of College Student Development, 38 (4), 387- 400.

Pusztai, G. (2008). Les bienfaits pedagogiques de la religiosité parmi les éleves hongrois de trois pays, Social Compass 55 (4), 497-516. doi: 10.1177/0037768608097235

Pusztai, B. (2009). Tértudat és tudatturizmus. In Michalkó G. \& Rácz T. (Eds.): A tér vonzásában (pp. 17-30). Székesfehérvár-Budapest: KJF MTA Földrajztudományi Kutatóintézet.

Pusztai, G. (2009a). A társadalmi tőke és az iskola. Kapcsolati eröforrások hatása az iskolai pályafutásra. Budapest: Új Mandátum Könyvkiadó.

Pusztai, G. (2009b). Mentor vagy idol? A doktorandusz-témavezető kapcsolat formái a tudományos utánpótlásképzésben. In Pusztai G. \& Rébay M. (Eds.): Kié az oktatáskutatás? Tanulmányok Kozma Tamás 70. Születésnapjára (pp. 337-353). Debrecen: Csokonai Kiadó. 
Pusztai, G. (2011). A láthatatlan kéztöl a baráti kezekig. Hallgatói értelmezö közösségek a felsőoktatásban. Budapest: Új Mandátum Könyvkiadó.

Pusztai, G. (2014). The Effects of Institutional Social Capital on Students' Success in Higher Education. Hungarian Educational Research Journal, 4(3), 68-83. doi: 10.14413/herj.2014.03.07

Pusztai, G. (2015). Pathways to Success in Higher Education Rethinking the Social Capital Theory in the Light of Institutional Diversity. Frakfurt am Main: Peter Langü.

Szczepanski, J. (1969). A felsőoktatás szociológiája. Budapest: Felsőoktatási Pedagógiai Kutatóközpont.

Thomas, L. (2002). Student retention in higher education: the role of institutional habitus. Journal of Education Policy, 17 (4), 423-442. doi: 10.1080/02680930210140257

Thomas, L. \& Jones, R. (2007). Embedding Employability in the Context of Widening Participation. York: The Higher Education Academy.

Umbach, P. D. (2007). How effective are they? Exploring the impact of contingent faculty on undergraduate education. The Review of Higher Education, 30 (2), 91- 124. 